Journal of Science Education Research

Journal homepage: www.journal.uny.ac.id/jser

JSER

\title{
The Effect of Problem Based Learning Based Sosio-Scientific Issues on Scientific Literacy and Problem-Solving Skills of Junior High School Students
}

\author{
Hestiana $^{1^{*}}$, Dadan Rosana ${ }^{2}$ \\ ${ }^{1,2}$,Study Program of Science Education, Faculty of Mathematics and Natural Sciences, Universitas Negeri Yogyakarta \\ Corresponding Author. Email: hestisabrina@gmail.com
}

Keywords:

Problem Based

Learning, Social-

Scientific

Problems, Science

Literacy, Problem

Solving Skills

\begin{abstract}
This study aims to analyze the effect of the Sosio-Scientific Issues (SSI) based Problem Based Learning (PBL) on increasing scientific literacy and problemsolving skills of junior high school students. The type of research is Quasi experiment with Nonequivalent Control Group Design. The population included class VII Junior High School of 6 Yogyakarta that consisting of seven classes in the 2019/2020 school year. The sample is determined by the Purposive Sampling technique. The research instruments were pretest and posttest questions of scientific literacy and students' problem-solving skills. Hypothesis testing is done with MANOVA and effect size calculation to find out how much influence is given. Based on the MANOVA test, the Sig value is 0,000 that $<\alpha(0.05)$ so that $\mathrm{Ha}$ is accepted (H0 is rejected). As for the calculation of the effect size obtained a score of 0.897 (high enough), which means that SSI-based PBL has a significant effect on increasing scientific literacy and a score of 1,027 (high), which means that SSIbased PBL has a high effect on improving students' problem-solving skills. Based on these results it can be concluded that PBI based on SSI affects the increasing scientific literacy and problem-solving skills.
\end{abstract}

C2020 JSER. Yogyakarta State University

\section{INTRODUCTION}

The science literacy community is urgently needed to answer and deal with global issues in the 21 st century. Students as part of the community need to be formed to become a society that is literate in science through learning scientific literacy. According to Anjarsari (2014), students who have scientific literacy will have the ability to care and respond to issues that develop in society, think critically and creatively, and have deep knowledge and understanding to be applied. PISA (Program for International Student Assessment) states that the ability of scientific literacy includes (a) the ability to explain scientific phenomena, (b) evaluating and designing scientific investigations, and (c) interpreting scientific data and evidence.

However, based on the results of PISA 2018, Indonesia obtained a score of 396 (OECD average 489) (OECD, 2019b). If related to level 7 the level of scientific literacy skills in the OECD document (2016), the score is at level 1a where students can only use basic or daily content and procedural knowledge to recognize or identify explanations of simple scientific phenomena. From the results of PISA 2018, it can also be seen that there are 2 provinces in Indonesia which have an average score of scientific literacy that is higher than the average score of Indonesia, namely DKI Jakarta (score 424) and D.I Yogyakarta (score 434). But the score is still at level 2, where students can only recognize correct explanations for known scientific phenomena and use that knowledge to identify, in simple cases, whether the conclusion is valid based on the data provided.

In line with the low level of literacy skills in Indonesian science, the results of Widyastutik \& Widodo's (2018) research on the competency profile of students' scientific literacy in the Yogyakarta City 
Junior High School in terms of the school's favorite level, states that the profile of scientific literacy competencies of students from high-favorite schools., moderate and low are enough, less and very less. Students' understanding of aspects of explaining phenomena scientifically is lacking, understanding of aspects of evaluating and designing scientific investigations is lacking and understanding of aspects of interpreting evidence and scientific data is lacking. These results are very unfortunate given the importance of scientific literacy competencies for the life of this century. Therefore the development of scientific literacy needs to be improved.

In addition to realizing a science literate society, learning science also emphasizes students' thinking patterns in order to be able to master and solve problems critically, logically, carefully and thoroughly so that they do not only understand concepts (Darwanti, 2013). Problem solving skills are one of the important skills that students must have because in everyday life everyone is always faced with various problems that must be solved and requires creativity in order to be able to find solutions to the problems they face (Permatasari \& Margana, 2014). The problem solving ability trains students to discover for themselves various concepts holistically, meaningfully, authentically and applicatively (Hariawan, Kamaluddin, \& Wahyono, 2013). According to Geege Polya (in Tambunan, 2014), the problem solving skills include understanding the problem, compiling a problem solving plan, implementing a problem solving plan, and re-examining the results obtained.

Based on observations on PLP (School Field Practice) activities in January 2019 in one of Yogyakarta City Junior High Schools, teachers tend to use LKPD derived from student books besides science learning also tends to be theoretical, where teachers display material at power points, students take notes later the teacher explained. Therefore, learning science is less meaningful for students. So in this case, learning has not led to contextual learning that is relevant to the problems of everyday life therefore students are rarely to practice their problem solving skills.

Science literacy is the ability to engage in science-related issues (OECD, 2019a) and problem solving skills are a person's basic skills in solving problems that involve critical, logical, and systematic thinking. Therefore, learning that is suitable for improving scientific literacy and problem solving skills is problem based learning that is integrated with science issues. The learning model is a problem based learning (PBL) based on socio-scientific issues (SSI).

Problem-based learning or known as ProblemBased Learning (PBL) according to Wisudawati \&
Eka (2014) is a learning model that aims to help students learn and discover concepts and solve problems by connecting problem situations in the real world. PBL also aims to help students develop thinking skills, problem solving, and intellectual skills (Cahyani \& Setyawati, 2016). Bahri, Putriana, \& Idris (2018) explained that PBL can train and improve students' abilities in problem solving, communicating and collaborating, as well as enabling various problem solving in different points of view.

Whereas SSI according to Karisan \& Zeidler (2017) can be used as a core tool to develop scientific literacy. Zeidler, Sadler, Simmons, \& Howes (2005) also stated that SSI can foster awareness or science literacy in students so that they can apply evidence-based science knowledge in everyday life. In addition, the application of SSI in science education can help students to develop critical thinking skills through discussion of social science topics (Roberto \& Bernando, 2012). As according to Yuliastini, Rahayu, \& Fajaroh (2016) by increasing mastery of students 'critical thinking concepts and skills due to the application of SSI in learning, students' scientific literacy will be achieved.

The combination of PBL and SSI models is a problem based learning model where the problem is based on socio-scientific issues (SSI). Based on the theories that have been put forward, the combination of PBL with the SSI context can provide tangible and more meaningful learning to students and is expected to be able to improve students' scientific literacy and problem solving skills.

Based on this description, researchers plan to examine the Effect of Problem Based Learning (PBL) Models Based on Socio-Scientific Issues (SSI) on Science Literacy in Problem Solving Skills of Junior High School Students.

\section{METHOD}

This research uses quasi experimental research (Quasi Experiment). The study was conducted at Yogyakarta 6 Public Middle School from January-March 2020. The study population included all class VII Yogyakarta 6 Public Middle School 2019/2020 school year totaling 237 students and divided into 7 classes. The research sample was selected using purposive sampling technique and obtained 2 classes, namely VIID class as a control class and VIIE as an experimental class. The study uses a non-equivalent control group design research design which is presented in Table 1. 
Table 1. Research Design

\begin{tabular}{llll}
\hline Group & Prestest & $\begin{array}{l}\text { Treatment } \\
(\mathrm{X})\end{array}$ & Posttest \\
\hline Experiment & O1A, & $\mathrm{X} 1$ & O3A, \\
Group & O1B & & O3B \\
Control & O2A, & $\mathrm{X} 2$ & O4A, \\
group & O2B & & O4B \\
\hline
\end{tabular}

Explanation:

$\mathrm{X} 1=$ Treatment with Problem Based Social-based Learning (PBL) Scientific Issues (SSI)

$\mathrm{X} 2=$ Treatment with $5 \mathrm{M}$ Learning

O1A $=$ Pretest of Science Literacy

$\mathrm{O} 2 \mathrm{~B}=$ Pretest Solving Skills Problem

$\mathrm{O} 3 \mathrm{~A}=$ Posttest of Science Literacy

O4B = Posttest Solving Skills Problem

Data collected includes data on scientific literacy skills and students' problem solving skills obtained through pretest-posttest. After the pretestposttest data is obtained, the N-Gain score calculation is performed using the following formula.

$$
\langle g\rangle=\frac{<\% \text { post }>-<\% \text { pre }>}{100 \%-<\% \text { pre }>}
$$

Explanation:

$\langle\mathrm{g}\rangle=$ average normalized gain

$\langle \%$ post $\rangle=$ percentage of the average Posttest value $<\%$ pre $>=$ percentage of average Pretest scores

$100 \%=$ maximum value

The results of the N-Gain calculation are interpreted with the following classification.

Table 2. Interpretations of N-Gain

\begin{tabular}{cl}
\hline Value of $\langle\mathrm{g}\rangle$ & Interpretation \\
\hline$-1.00 \leq g<0.00$ & There has been a \\
$\mathrm{g}=0.00$ & Therine \\
$0.7<g<1$ & High \\
$0.3 \leq g \leq 0.7$ & Is \\
$0<g<0.3$ & Low Interpretation \\
\hline
\end{tabular}

Source: Sundayana, 2014

Furthermore, the N-Gain score in the prerequisite tests includes tests of normality (Kolmogorov Smirnov) and homogeneity (Levene's Test of Equality of Error Variances). Then do the hypothesis test in the form of MANOVA on the NGain score and also the calculation of effect size through the following formula.

$d=\frac{\bar{x}_{1}-\bar{x}_{2}}{s_{g a b}}$.

with

$S_{g a b}=\sqrt{\frac{\left(n_{1}-1\right) S_{1}^{2}+\left(n_{2}-1\right) S_{2}^{2}}{n_{1}+n_{2}-2}}$
Explanation:

$\mathrm{d}=$ effect size

$\bar{x}_{1} \quad=$ the average of the experimental class

$\bar{x}_{2}=$ the average of the control class

$S_{g a b}=$ standard deviation combined

$n_{1} \quad=$ the number of students in the experimental class

$n_{2} \quad=$ the number of students in the control class

$S_{1}^{2} \quad=$ the variance of experimental class

$S_{2}^{2} \quad=$ the variance of control class

The interpretation of Effect Size can be explained as in Table 3 below.

Table 3. Interpretations of Effect Size

\begin{tabular}{cc}
\hline Effect Size & Category \\
\hline $0-0.5$ & Low \\
$0.6-0.8$ & High enough \\
$0.9-3$ & High \\
\hline
\end{tabular}

Source: Becker, 2000

In this case, the analysis prerequisite test and MANOVA were performed using SPSS statistical software 22.

\section{RESULT}

This study aims to analyze the effect of SosioScientific Issues (SSI) based Problem Based Learning (PBL) on improving scientific literacy and problem solving skills of junior high school students. The data obtained in this study are pretestposttest data on scientific literacy and problem solving skills. Based on research that has been done, obtained posttest data as in Figure 1 below.

\section{The Comparison of Posttest Scores}

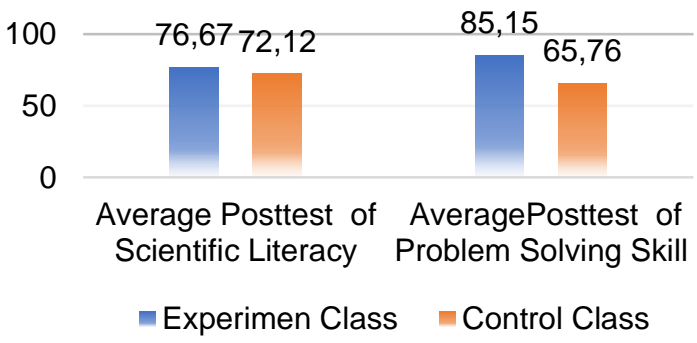

Figure 1. The Comparison of Posttest Scores

From Figure 1. it can be seen that the posttest scores of science literacy and problem solving skills of students of the experimental class are higher than those of the control class. This is because learning through PBL can place problems as a starting point for learning. Through problems, students also learn and try to find solutions to problems and develop thinking skills and problem solving abilities (Lismayani \& Mahanal, 2017). Problem-based 
learning is actually learning that uses authentic problems to solve. The authentic problems that are effectively used in learning are social problems related to science (Socio-Scientific Issues) as in this study. Socio-Scientific Issues are important in science education because SSI is used as a core tool for developing scientific literacy (Karisan \& Zeidler, 2017).

These results are in accordance with Rizkita, Suwono, \& Susilo (2016) who conducted research on the effect of socio-scientific problem based learning on student cognitive learning outcomes where the average posttest score (71.03) of the experimental class was $62.9 \%$ higher than in the control class. In addition, Sumiantari, Suardana, \& Selamet (2019) in their research on the effect of Problem Based Learning on the problem solving ability of junior high school students also revealed that the average value of the posttest in the experimental class was higher than the control class

This is reinforced by the results of N-Gain calculations or improvement in scientific literacy and problem solving skills of students in the control and experiment class as shown in the following figure 2 .

The Comparison of $\mathrm{N}$-Gain Scores

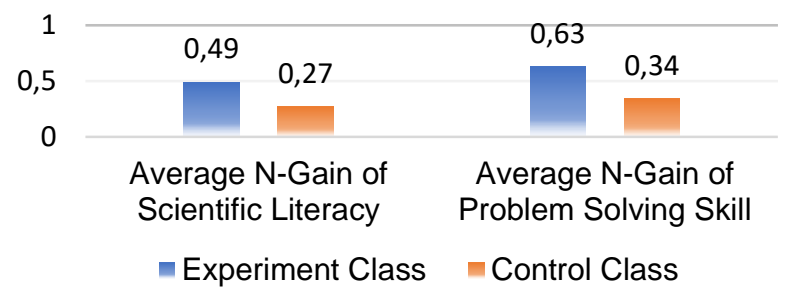

Figure 2. The Comparison of N-Gain

Based on Figure 2, the N-Gain score of the experimental class is higher than the control class. For scientific literacy the experimental class has an $\mathrm{N}$-Gain score of 0.49 (medium category) while the control class has an N-Gain score of 0.27 (low category). As for problem solving skills, the experimental class had an N-Gain score of 0.63 (medium category) and a control class of 0.34 (medium category).

The difference in the increase in scientific literacy is due to the SSI applied in learning in this study can help students to develop critical thinking skills through discussion of social science topics (Roberto \& Bernando, 2012) and in this study, students also discuss the Socio topic -Scientific Issues (global warming), i.e. discuss with the group in identifying SSI, assessing its impact, and giving decisions related to what should be done on SSI issues. Yuliastini et al. (2016) bright added that by increasing the mastery of concepts and critical thinking skills of students due to the application of
SSI in learning, the scientific literacy of students will be achieved.

As for the difference in the improvement of students' problem solving skills between the experimental class and also the control class due to problem solving learning can provide provision and direct experience in implementing problem solving strategies to solve the problems faced (Gok, 2014).

The effect of SSI-based PBL on improving scientific literacy and problem solving skills of junior high school students was analyzed using the MANOVA test (Multivariate test). Based on these tests, the value of Sig. of 0,000 which is smaller or less than the significance level of $0.05(\alpha=5 \%)$ so $\mathrm{Ha}$ is accepted (H0 is rejected) which means there is a difference in the increase in the value of scientific literacy and problem solving skills between classes using Problem Based Learning based on SocioScientific Issues with control class. In other words, SSI-based PBL learning influences the improvement of science literacy and problem solving skills of junior high school students. These results are in line with the research of Lismayani \& Mahanal (2017) where the application of Problem Based Learning (PBL) is effective in improving students' problem solving abilities. The existence of issue-based learning also influences students' social science problem solving abilities (Muhammad, 2019). In addition, Ardianto \& Rubini (2016) states that the application of PBL can build students' scientific literacy competencies.

Science literacy competencies can be held through SSI in science education that emphasizes the application of scientific and moral reasoning to deal with phenomena that occur in society. The SSI is effective in increasing students' understanding of science in various contexts, argumentation skills, empathy, and moral reasoning (Lathifah \& Susilo, 2015).

According to Diana et al. , (2015), so that the ability of scientific literacy can improve well, the instructors are encouraged to start introducing and learning material by using various strategies that can practice the ability of scientific literacy, including learning material through experiments that can stimulate higher-order thinking and contextual .

In this case, researchers apply Problem Based Learning based on Socio-Scientific Issues. In this learning, students conduct problem solving-based investigation practicum, which is preceded by identification of socio-scientific issues, study of the impact of socio-scientific issues and the formulation of problems. According to Sutarno et. al., (2017), the application of problem solving based practice can practice higher order thinking skills. PBL also teaches real-world problems as a context for students to learn about critical thinking and their solving skills, and to obtain essential knowledge and 
concepts (Cahyani \& Setyawati, 2016). Thus, problem-based learning based on socio-scientific issues is suitable for practicing students' scientific literacy skills because it is contextual and can stimulate students to higher order thinking.

In problem-based learning (Problem Based Learning), the problem is used as a stimulus and focus for students' learning activities. By making the problem as a stimulus and focus of learning activities in school, students will be trained in developing problem solving skills in everyday life. This is in accordance with the educational objectives conveyed by Memnun (2012), that education should enable individuals to obtain problem solving skills and train individuals to overcome problems encountered during their real lives. In addition to training and improving students' abilities in problem solving, PBL also trains and enhances the ability to communicate and collaborate. (Bahri, Putriana, \& Idris, 2018).

The problems used in PBL in this research are social-science related issues or Socio-Scientific Issues. Referring to Presley et al. (2013), one of the SSI that can be used is issues related to environmental problems such as global warming and climate change. The issue is appropriately taken because it is contextual close to the lives of students. Hastuti, Tiarani, \& Nurita (2018) explained that the application of learning that involves science issues will practice problem solving skills, so that it will increase high-level thinking, discussion skills, investigation and understanding of science facts.

Rostikawati \& Permanasari, (2016) also added that SSI-based learning is very potential if used as a basis for learning science in schools. The use of SSI can be used as a link to real problems in the community and the foundation by learners in exploring science content. The ability of students to link science theory with social-science problems that occur in society can train students to find solutions to solve problems that occur in the community (Suwono, Rizkita, \& Susilo, 2015). The process has occurred in Socio-Scientific Issuesbased Problem Based Learning, where students are confronted with community problems related to science (Global Warming) and learn to find solutions to these problems.

Based on the explanation above, besides being suitable for practicing students 'scientific literacy skills because it is contextual and can stimulate students to think at a higher level, Problem Based Learning based on Socio-Scientific Issues is also suitable for training and improving students' problem solving abilities. This is in accordance with the results of this study where Problem Based Learning based on Socio-Scientific Issues influences and improves the ability of scientific literacy and problem solving skills of students.
To find out the effect of SSI-based PBL on each variable, an effect size calculation analysis was performed. Based on the analysis, a score of 0.897 (high enough category) was obtained for the effect of SSI-based PBL on scientific literacy, and a value of 1.027 (high category) for the influence of SSIbased PBL on students' problem solving skills. Seeing these results it can be proven that Problem Based Learning based on Socio-Scientific Issues affects the scientific literacy and problem solving skills of students.

\section{CONCLUSION}

Based on the results of research and discussion, it can be concluded that there is an influence of the Problem Based Learning Model Based on Socio-Scientific Issues on increasing scientific literacy and problem solving skills of junior high school students based on the results of MANOVA (Multivariate Test) analysis with Sig. $(0,000)<\alpha(0.05)$ so $\mathrm{H} 0$ is rejected (Ha is accepted). Based on the calculation of the effect size, the influence of the Sosio-Scientific Issues-Based Problem Based Learning model on scientific literacy is 0.897 with a high enough category and on problem solving skills is 1.027 with a high category.

\section{REFERENCES}

Anjarsari, P. (2014). Literasi Sains Dalam Kurikulum dan Pembelajaran IPA SMP. In Seminar Nasional Pensa VI "Peran Literasi Sains" (pp. 602-607). Surabaya, Indonesia.

Ardianto, D., \& Rubini, B. (2016). Comparison of Students' Scientific Literacy in Integrated Science Learning Through Model of Guided Discovery and Problem Based Learning. Jurnal Pendidikan IPA Indonesia, 5(1), 3137.

Bahri, A., Putriana, D., \& Idris, I. S. (2018). Peran PBL dalam Meningkatkan Keterampilan Pemecahan Masalah Biologi The Role of PBL in Improving Biological ProblemSolving Skill. Jurnal Sainsmat, VII(2), 114124.

Becker, L.A., (2000). Effect Size (ES). Journal: Effect Size Measures for Two Independent Group. Retrieved Januari 6, 2020, from http;//web.uccs.edu/lbecker/Psy590/es.html.

Cahyani, H., \& Setyawati, R. W. (2016). Pentingnya Peningkatan Kemampuan Pemecahan Masalah melalui PBL untuk Mempersiapkan Generasi Unggul Menghadapi MEA. In Seminar Nasional Matematika X UNNES (pp. 151-160). Semarang.

Darwanti, A. (2013). Upaya Peningkatan Hasil Belajar Ipa Dengan Creative Approach 
Berbasis Pictorial Riddle Approach Pada Siswa Kelas V Sdn 03 Karangsari Jatiyoso Tahun Pelajaran 2012/2013. Universitas Muhammadiyah Surakarta.

Diana, S., Rachmatulloh, A., \& Rahmawati, E.S. (2015). Profil Kemampuan Literasi Sains Siswa SMA Berdasarkan Instrumen Scientific Literacy Assesment (SLA). In Seminar Nasioanl XII, Pendidikan Biologi FKIP UNS (Vol. 201).

Gok, T. (2014). Students' achievement, skill and confidence in using stepwise problem-solving strategies. Eurasia Journal of Mathematics, Science \& Technology Education, 10(6), 617624.

Hariawan, Kamaluddin, \& Wahyono, U. (2013). Pengaruh model pembelajaran creative problem solving terhadap kemampuan memecahkan masalah fisika pada siswa kelas XI SMA Negeri 4 Palu. Jurnal Pendidikan Fisika Tadulako (JPFT), 1(2), 48-54.

Hastuti, P. W., Tiarani, V. A., \& Nurita, T. (2018). The Influence of Inquiry-Based Science Issues Learning on Practical Skills of Junior High School Students. Jurnal Pendidikan IPA Indonesia, 7(2), 232-238.

Karisan, D., \& Zeidler, D. L. (2017). Contextualization of Nature of Science Within the Socioscientific Issues Framework: A Review of Research Contextualization of Nature of Science Within the Socioscientific Issues Framework: A Review of Research. International Journal of Education in Mathematics, Science and Technology, 5(2), 139-152.

Lathifah, A. S., \& Susilo, H. (2015). Penerapan Pembelajaran Socioscientific Issue Melalui Metode Simposium Berbasis Lesson Study Untuk Meningkatkan Kemampuan Berpikir Kritis Mahasiswa Pada Matakuliah Biologi Umum. In Prosiding Seminar Nasional Pendidikan Biologi UMM (pp. 9-19). Malang.

Lismayani, I., \& Mahanal, S. (2017). Efektivitas Problem Based Learning (PBL) Dalam Meningkatkan Kemampuan Pemecahan Masalah. In Prosiding TEP \& PDs: Transformasi Pendidikan Abad 21 (pp. 737748).

Memnun, D.S., et al. (2012). A Research on The Mathematical Problem Solving Belief of Mathematics, Science and Elementary PreService Teacher in Turkey in Term 78 of Different Variable. Internasional Journal of Humanities and Social Science, 24(2).

Muhammad, M., Lestari, A. F., \& Lencau, I. (2019). Pengenalan Pembelajaran Berbasis Isu Terhadap Kemampuan Pemecahan Masalah
Sosial Sains dan Sikap Sosial Siswa SDN 016 Tarakan. Jurnal Pendidikan Dasar Borneo (Judiknas Borneo), 01(01), 58-68.

OECD. (2016), PISA 2015 Results (Volume I): Excellence and Equity in Education, PISA, OECD Publishing, Paris, http://dx.doi.org/10.1787/9789264266490-en (2019a). PISA 2018 Science Framework, in PISA 2018 Assessment and Analytical Framework. Paris: OECD Publishing, Retrieved Januari 2, 2020, from https://doi.org/10.1787/b25efab8-en.

(2019b). PISA 2018 Result: Combine Executive Summaries Volume I, II, \& III. OECD Publishing. Retrieved Januari 2, 2020, from www.oecd.org/pisa/Combined_Excutive_Su mmaries_PISA_2018.pdf.

Permatasari, N. Y., \& Margana, A. (2014). Meningkatkan Kemampuan Siswa Dalam Memecahkan Masalah Matematika Dengan Model Pembelajaran Treffinger. Jurnal Pendidikan Matematika, 3(1), 31-42.

Presley, M. L., Sickel, A. J., Muslu, N., Merle-, D., Witzig, S. B., Izci, K., \& Sadler, T. D. (2013). A Framework for Socio-scientific Issues Based Education. Science Educator, 22(1), 26-32.

Rizkita, L., Suwono, H., \& Susilo, H. (2016). Pengaruh Pembelajaran Socio-Scientific Keterampilan Metakognitif dan Hasil Belajar Kognitif Siswa Kelas X SMAN Kota Malang. Jurnal Pendidikan: Teori, Penelitian, Dan Pengembangan, 1(4), 732-738.

Roberto, J. \& Bernardo, R. (2012). The Pre-Service Physics Teacher and The Challenge of The Socioscientific Issues-Based Approach. Dalam C. Bruguire, A. Tiberghien \& P. Clement (Eds), E-Book Proceeding of The ESERA 2011 Conference: Science Learning and Citizenship. Part 7 (co-ed. V. Albe \& B. Evans), (hlm.17-23). France: European Science Education Research Association.

Rostikawati, D. A., \& Permanasari, A. (2016). Rekonstruksi Bahan Ajar dengan Konteks Socio-Scientific Issues pada Materi Zat Aditif Makanan untuk Meningkatkan Literasi Sains Siswa, 2(2), 156-164.

Sumiantari, N. L. E., Suardana, I. N., \& Selamet, K. (2019). Pengaruh Model Problem Based Learning Terhadap Kemampuan Pemecahan Masalah IPA Siswa Kelas VIII SMP. Jurnal Pendidikan Dan Pembelajaran Sains Indonesia Volume, 2(1), 12-22.

Sundayana, R. (2014). Statistika Penelitian. Bandung: Alfabeta.

Sutarno, S., Setiawan, A., Kaniawati, I., \& Suhandi, A. (2017). Pre-Service Physics Teachers' 
Problem-Solving Skills In Projectile Motion Concept. In Journal of Physics: Conference Series, 895(1). IOP Publishing.

Suwono, H., Rizkita, L., \& Susilo, H. (2015). Peningkatan Literasi Saintifik Siswa SMA Melalui Pembelajaran Biologi Berbasis Masalah Sosiosains. Jurnal Ilmu Pendidikan, 21(2), 136-144.

Tambunan, H. (2014). Strategi Heuristik dalam Pemecahan Masalah Matematika Sekolah. Jurnal Saintech, 6(4), 35-40.

Widyastutik, L. R., \& Widodo, E. (2018). Profil Aspek Kompetensi Literasi Sains Pada Siswa Kelas VIII di SMPN Kota Yogyakarta Ditinjau Dari Tingkat Kefavoritan Sekolah. E-Journal Pendidikan IPA, 7(1), 33-39.
Wisudawati, A. W., \& Eka, S. (2014). Metodologi Pembelajaran IPA: Disesuaikan dengan Kurikulum 2013. Jakarta: Bumi Aksara.

Yuliastini, I. B., Rahayu, S., \& Fajaroh, F. (2016). POGIL Berkonteks Socio Scientific Issues (SSI) dan Literasi Sains Siswa SMK. In Prosiding Seminar Nasional Pendidikan IPA Pascasarjana UM (pp. 601-614). Malang.

Zeidler, D. L., Sadler, T. D., Simmons, M. L., \& Howes, E. V. (2005). Beyond STS: A Research-Based Framework for Socioscientific Issues Education. Journal of Science Education, 357-377. 